\title{
Cultural additivity and WEIRDness
}

\author{
Manh-Tung Ho \\ Ritsumeikan Asia Pacific University, \\ Beppu, Oita, Japan \\ January $13^{\text {th }}, 2021$
}

In a Commentary published in Nature 2010 [1] titled "Most people are not WEIRD," following a paper in Behavioral and Brain Sciences [2], Joseph Henrich, Steven J. Heine, and Ara Norenzayan coined the acronym WEIRD, i.e., Western, educated, industrialized, rich, and democratic, to designate the population sample that has been extensively studied in the behavioral and psychological literature. He pointed out that the scholars in this field had frequently made universal claims about human behaviors and psychology without providing any caveats for the fact the WEIRD sample is massively biased, and the psychological characteristics of this sample are distributed at the extreme. These papers have fared rather well, with the later accumulated 3,441 Crossref citations and the former 711 citations.

After ten years, the lead author, Joseph Henrich, published a book titled "The Weirdest People in the World: How the West Became Psychologically Peculiar and Particularly Prosperous" [3]. Building on the two articles mentioned above, the author seeks to provide a comprehensive account of two issues:

1) What are the major psychological and behavioral traits of the WEIRD people?

2) Why do these people become WEIRD?

For the first problem, Henrich draws on an extensive literature on the cross-cultural differences in psychological and behavioral traits, spearheaded by researchers such as Richard Nisbett with concepts such as "Geography of thoughts" [4,5] or Geert Hofstede's "cultural dimensions" [6]. Here is a quick recap of the major traits in WEIRD psychology, according to Joseph Henrich.

The WEIRD people tend to be more individualistic. They conceptualize themselves more as an individual self with a particular set of dispositions; for example, when asked to fill in the 
blank "I am __," the WEIRD people tend to write "curious," "hard-work," etc., while people from many collectivistic cultures tend to write "father," "mother," etc. They are more likely to experience guilt than shame, with guilt being a more self-oriented feeling, while shame is more others-oriented. The WEIRD score higher on the impersonal pro-sociality scale, i.e., they try to follow impartial principles over contextual particularism; they are more likely to trust strangers and impersonal institutions and focus more on mental states when making a moral judgment. The WEIRD people's cognitive style is more analytic than holistic. The book is well-referenced with empirical articles to back up these claims.

To explain why the WEIRD people become the way they are: impersonally prosocial, time-thrift, individualistic, and analytic, Henrich attributes this change in the way of being to the choices made by the Christian Church that prohibited cousin marriage between AD1000 and 1500. This had resulted in the reduction of the traditional kinship network, which forces people to evolve the psychological and behavioral traits above that are arguably more adaptive when people have to deal with strangers more often. Henrich then further argues these traits allow the Industrial Revolutions to happen in European societies rather than in Chinese or the Islamic world. They also enable the West to become more prosperous and innovative.

Here, one has to say Henrich's account of the Industrial Revolution is also rather WEIRD. We must question this cultural deterministic account as no one can be sure of the causal relationship between people become WEIRD and countries become richer and more industrialized. We would never know if the Industrial Revolution happens merely by chance, and forces the WEIRDness to evolve because the WEIRD traits are more adaptive in the industrialized setting. Or there can be a feedback loop, i.e., as society goes through certain changes, it makes certain other changes more likely. For example, people start to have WEIRD mindsets, which make capitalistic, industrial, consumeristic living works, which in turn, makes people WEIRDer. Culture, economy, society are marco-entities that co-evolve with each other under a complex process [7].

Critics of Henrich's book argue that the gravest issue was the failure to explain the darker aspects of the WEIRD's civilization such as racism, imperialism, plunder, and genocide. Henrich admits, perhaps too dismissively, that "there are plenty of books on those subjects" in his final chapter [8]. If we follow Henrich's account, then we must conclude that the WEIRD's 
impersonal pro-sociality was only reserved for Europeans when they first started to conquer outside of Europe. If impartial principles are so valued in the WEIRD psyche, how do we explain nepotism displayed by Trump or Boris Johnson, and countless other Western politicians [8]? To be fair, Henrich did make a point that emboldened by their own impartial values, and WEIRD people tended to assume what is good or bad for them is good or bad for others.

The deeper problem with Henrich's argument, in my opinion, is that the treatment of the mental process of adopting new cultural values as static rather than dynamic. Henrich did posit all of the psychological traits are located in a spectrum. For example, an analytical thinking style is at one end and the holistic style the other, this kind of thinking undermines the dynamic process of values. It enables contradicting values to coexist in culture and one person's mind $[9,10,11]$. To this end, we'd better think of the mind as a sponge that continually evaluates, filters, ejects, and adds cultural values [12,13]. There is a core set of values that does that filtering, when new values are successfully adopted by this core, the mind use the new core to continually assess and select suitable values. Thinking in this way, the binary classification of opposing values provided by WEIRD thinkers like Henrich is too linear. In reality, the mind is more dynamic, non-linear, as contradicting values or traits can be accommodated. We can see the extreme case of this process among WEIRD Trump supporters. The mindsponge model allows us to envision a mind accommodating contradicting values in different ways: it can have the core of the analytic thinking style, for example, and the periphery is the holistic thinking style; or it can move fluidly between the two styles depending on the socio-cultural settings and situations, one can become more active than the other [9,10,14].

With that in mind, there is a possibility of unWEIRDing our way of thinking about human behavior and psychology in the future, although it requires some serious degree of unlearning to the extent that needs the activating of mindsponge processes $[12,13]$ on a large scale.

\section{References}

1. Henrich, J., Heine, S. J., \& Norenzayan, A. (2010). Most people are not WEIRD. Nature, 466(7302), 29-29. doi:10.1038/466029a 
2. Henrich, J., Heine, S. J., \& Norenzayan, A. (2010). The weirdest people in the world? Behavioral and Brain Sciences, 33(2-3), 61-83. doi:10.1017/S0140525X0999152X

3. Henrich, J. (2020). The WEIRDest people in the world: How the West became psychologically peculiar and particularly prosperous. London: Farrar, Straus and Giroux.

4. de Oliveira, S., \& Nisbett, R. E. (2017). Culture changes how we think about thinking: From "Human Inference" to "Geography of Thought". Perspectives on Psychological Science, 12(5), 782-790.

5. Nisbett, R. (2004). The geography of thought: How Asians and Westerners think differently... and why. New York: Simon and Schuster.

6. Hofstede, G. (2011). Dimensionalizing cultures: The Hofstede model in context. Online readings in psychology and culture, 2(1), 2307-0919.1014.

7. Phạm Minh Chính, Vương Quân Hoàng. (2009). Kinh tế Việt Nam: Thăng trầm và đột phá. Nxb Chính trị Quốc gia, Hà Nội.

8. Guyatt, N. (2020). The Weirdest People in the World review - a theory-of-everything study. The Guardian. Retrieved January 11, 2021 from https://www.theguardian.com/books/2020/nov/20/the-weirdest-people-in-the-worldreview-a-theory-of-everything-study

9. Vuong, Q.-H., Bui, Q.-K., La, V.-P., et al. (2018). Cultural additivity: behavioural insights from the interaction of Confucianism, Buddhism and Taoism in folktales. Palgrave Communications, 4(1), 143. doi:10.1057/s41599-018-0189-2

10. Vuong, Q.-H., Ho, M.-T., Nguyen, H.-K. T., et al. (2020). On how religions could accidentally incite lies and violence: folktales as a cultural transmitter. Palgrave Communications, 6(1), 82. doi:10.1057/s41599-020-0442-3

11. Vuong, Q.-H., Bui, Q.-K., La, V.-P., et al. (2019). Cultural evolution in Vietnam's early 20th century: A Bayesian networks analysis of Hanoi Franco-Chinese house designs. Social $\begin{array}{lllll}\text { Sciences } \quad \text { H } & \text { Open }, & 1(1), & 100001 .\end{array}$ doi:https://doi.org/10.1016/j.ssaho.2019.100001 
12. Vuong, Q. H. (2016). Global mindset as the integration of emerging socio-cultural values through mindsponge processes: A transition economy perspective. In J. Kuada (Ed.), Global Mindsets: Exploration and Perspectives (pp. 109-126). London: Routledge.

13. Vuong, Q. H., \& Napier, N. K. (2015). Acculturation and global mindsponge: an emerging market perspective. International Journal of Intercultural Relations, 49, 354-367.

14. Small, S., \& Blanc, J. (2021). Mental health during COVID-19: Tam Giao and Vietnam's response. Frontiers in Psychiatry, 11(1507). doi:10.3389/fpsyt.2020.58961 